\title{
ECONOMIC GROWTH IN CROATIA: POTENTIAL AND CONSTRAINTS ${ }^{1}$
}

David Moore, $\mathrm{PhD}$

Article*

International Monetary Fund, Washington

UDC 330.35

Athanasios Vamvakidis, $\mathrm{PhD}$ JEL E60, O11

International Monetary Fund, Washington

\section{Abstract}

This paper examines the factors and constraints that affect recent and potential growth in Croatia, as well as policies that can influence it. On current productivity trends, it estimates Croatia's potential growth rate at 4-41/2 percent, a result reasonably robust to different methodologies. For growth to be sustained at a significantly higher rate, the business environment needs to be improved through further measures to reduce the administrative burden, legal uncertainties, and corruption. The analysis also emphasizes the importance of attracting more greenfield foreign direct investment, and reforms to reduce the role of the state in the economy through fiscal consolidation and faster privatization.

Keywords: economic growth, economic reform, potential growth

\section{Introduction}

Croatia has experienced solid economic performance over the past five years, though room remains for improvement. Croatia's average real GDP growth has lagged behind performance in comparable regional transition economies. Despite its many natural ad-

${ }^{1}$ An earlier version of this paper was prepared as a Selected Issues paper for the IMF 2006 Article IV consultation for Croatia and was issued as an IMF Working Paper (WP/07/198). The authors would like to thank Martina Dalić, Robert A. Feldman, Nikolay Gueorguiev, participants at a seminar at the Croatian National Bank and two anonymous referees for useful comments and suggestions. The views expressed in the paper are those of the authors and do not necessarily represent those of the IMF or IMF policy.

* Received: August 2, 2007

Accepted: January 27, 2008 
vantages, Croatia has attracted only modest inflows of "greenfield" investments. Export performance has been below par, and survey measures of competitiveness consistently point to a difficult business environment.

This paper examines recent and prospective economic growth performance, with a view to answering the following questions:

-What pace of economic growth can Croatia expect in the medium term?

- How can this pace be increased? In this context, what factors constrain economic growth, and how can policies tackle these constraints?

The quest for economic growth has a number of facets. Questions related to what determines the potential growth rate and what reforms could increase it should be central to deciding a country's policy agenda. In the context of the Croatian economy, a relevant question is the extent to which the solid growth performance in recent years has been driven by fundamentals and therefore can be considered sustainable, and to what extent it has been driven by temporary factors. Structural reforms related to the transition process since the mid-1990s and to EU harmonization more recently, as well as macroeconomic adjustment to safeguard economic stability in recent years, should have increased Croatia's potential growth rate. Looking forward, policymakers need to know what policies and reforms could increase Croatia's growth rate further and lead to a faster income convergence to the EU.

The paper is set out as follows. Section II summarizes the main features of recent economic performance and surveys some of the potential underlying determinants. Section III estimates potential growth for Croatia over the next five years using standard statistical and production-function methodologies. These estimates suggest that on current productivity trends, Croatia's potential growth rate is between 4 and $4 \frac{1}{2}$ percent. Section IV corroborates these estimates using a cross-country econometric model for growth, and draws out some implications of how policy reforms could influence growth. Section $\mathrm{V}$ takes a different perspective by using the "growth diagnostic" approach to identify the binding constraints on growth. Section VI concludes with a discussion of policies needed to sustain higher growth rates in line with aspirations.

\section{Stylized Facts and the Determinants of Economic Growth}

Economic growth has been solid in recent years, though slightly below regional standards. Real GDP growth averaged 4.8 percent annually over $2002-06$, slightly below the peer country average over 2002-06 of nearly 6 percent (Figure 1). ${ }^{2,3}$ Nevertheless, this performance represents a pickup from Croatia's average economic growth of some $3 \frac{1}{4}$ percent annually over 1997-2001. Recent growth has relied on strong domestic investment.

Export performance has been disappointing. Real export growth averaged 6 percent annually during 2002-2006, significantly below the peer country average (over 10 percent).

${ }^{2}$ As set out in the Government of the Republic of Croatia (2006). For an earlier elaboration of a long-term growth strategy for Croatia, see Mihaljek (2001).

${ }^{3}$ For detailed discussions on the factors behind Croatia's growth experience in the 1990s, see Mervar and Nestić (1999) and Vujčić and Lang (2002). 
In contrast to GDP growth, export growth fell compared to the previous period (when it averaged $6 \frac{1}{2}$ percent over $1997-2001$ ). At the same time, recent economic performance has been associated with heightened external vulnerabilities. ${ }^{4}$ External debt jumped from $61 \frac{1}{2}$ percent of GDP at end-2001 to nearly 80 percent by end-2004, subsequently increasing to 85 percent at end-2006. The current account deficit averaged 6 percent of GDP during 2001-2005, and widened in 2006 to 7.6 percent of GDP.

Total foreign direct investment (FDI) into Croatia is close to the regional average (averaging just below 5 percent of GDP annually during 2002-2006), but "greenfield" FDI has been well below potential. UNCTAD data on the number of new greenfield FDI projects suggests that Croatia has lagged in attracting new investors (Figure 2). While these data need to be interpreted cautiously in the absence of comparable data on the size of projects, other evidence also points to underlying weakness in greenfield FDI. In a cross-country study for southeastern Europe, Demekas et al. (2005) estimate a gravity model for "potential" nonprivatization FDI (which captures greenfield FDI) using data up to 2003. They find that the estimated gap (underperformance) between actual and potential FDI in Croatia is one of the largest in the region. Moreover, other empirical evidence suggests that the financial sector has received a very large share of FDI (both privatization and new capital, and therefore not of the "greenfield" variety). This is the case whether looking over an extended period (30 percent of total inflows over 1993-2006) or more recently (over 40 percent of FDI each year in 2004-2006, partly reflecting capital injections to foreign-owned banks).

Croatia's progress in transition has lagged behind that of the top reforming countries. Looking at Croatia's reform progress in recent years in more detail, progress relative to other economies has been slower in a number of areas. According to the EBRD transition indicators up to 2006, Croatia's overall transition compares well with most south and eastern European economies, but lags behind transition in central European economies (Figure 3). Croatia's transition rank has not changed during recent years despite progress in all aspects of the process. And Croatia still lags behind most other transition economies in competition policy, large-scale privatization, and price liberalization. According to the EFN index of economic freedom (up to 2004), Croatia has progressed in most areas of macroeconomic and structural reform measured by the index, but by less than the rest of the world. As a result, Croatia's ranking for the overall EFN index has fallen over the past ten years.

A vast empirical literature has identified a multitude of factors that can determine economic growth. ${ }^{5}$ Based on the main results from this literature, we compare below the main possible determinants of growth in Croatia with those in the rest of Europe.

${ }^{4}$ Croatia's national accounts have undergone substantial improvements in recent years, but shortcomings remain. Significant discrepancies exist between expenditure-based and value-added-based GDP data stemming from problems in reconciling estimated tourism receipts, incomplete coverage of unincorporated businesses and the self-employed, inadequate data for measuring changes in inventories, incomplete coverage of the informal sector, and inadequate price deflators. Anecdotal evidence also suggests a large underground economy, which implies that actual production may be considerably higher than estimated GDP. Although inclusion of the underground economy in GDP estimates would affect ratios to GDP, it is not expected to affect significantly the trend GDP growth.

${ }_{5}^{5}$ Accordingly, policies aiming to mitigating external vulnerabilities were central to the authorities' program under Croatia's 2004-2006 Stand-By Arrangement with the International Monetary Fund. 
These results also allow us to simulate an empirical growth model for Croatia, estimate Croatia's potential growth, and quantify the growth impact of economic and structural reforms (see below).

Several stylized facts emerge from a cross-country comparison of growth determinants. The Appendix compares the main growth determinants in Croatia with selected neighboring and regional economies in southeastern Europe (SEE), other peer economies in central and eastern Europe (CEE), and the euro area. The table in the Appendix shows several alternative indicators for each growth determinant for recent years, depending on data availability. The literature has found that each of these variables significantly affects economic growth. Cross-country comparisons of their values can highlight the factors driving growth in Croatia relative to other countries in Europe, the factors in which Croatia lags behind, and the reforms on which Croatia should focus in order to increase growth in the future. According to these comparisons, in terms of growth prospects:

Croatia compares well with other transition economies with respect to:

- potential for convergence, with GDP per capita (in purchasing power standards) reaching 48 percent of the euro area average;

- public sector investment, spending considerably more as a share of GDP than other SEE and CEE countries;

- monetary policy, with low inflation, broadly in line with inflation rates in most of the rest of Europe;

- demographics, with a high dependency ratio but similar to that in the rest of Europe;

- infrastructure, where based on EBRD indicators reform is close to what seen in other transition economies;

- education, with enrollment ratios and spending per student close to the rest of Europe for both primary and secondary education, and a level of labor force education that does not give particular reason for concern - although more detailed data on human capital are more alarming (see below);

- health of the population, according to most indicators, although this comes at a relatively high cost since Croatia's public sector spends considerably more on health care as a share of GDP than both the SEE and CEE countries;

- the new economy, with the use and production of information technology broadly as developed as in the CEE, although less than in the euro area;

- financial sector, with a more advanced banking sector than that of most SEE and CEE countries and a limited presence of the state in the sector; ${ }^{6}$ and

- international trade, with all indicators suggesting a very open economy.

Croatia does not compare as well with other transition economies with respect to:

- $F D I$, with Croatia attracting only low levels of greenfield FDI;

${ }^{6}$ For more details, see Levine and Renelt (1992); Fischer (1993); Barro and Sala-í-Martin (2004); George, Oxley, and Carlaw (2004); Helpman (2004); Aghion and Durlauf (2005); and the Economic Growth Resources website (http:// www.bris.ac.uk/Depts/Economics/Growth/, updated by Jonathan Temple). 
- government size, with general government spending as a share of GDP well above levels in the SEE and the CEE countries, despite fiscal consolidation in recent years ${ }^{7}$

- transition, lagging behind the CEE countries, particularly in large-scale privatization, ${ }^{8}$ enterprise restructuring, competition policy, and price liberalization, ${ }^{9}$ and with a more significant role of the state in the economy than in the rest of Europe;

- the business environment, which is less friendly than that in the CEE countries and in the euro area according to almost all indicators (Figure 4);

- the legal system, with indicators for property rights, contract enforcement, and corruption less favorable than in both the CEE countries and the euro area; and

- the labor market, with a relatively high unemployment rate, in particular for the longterm unemployed and the young, and a low labor force participation rate, which very likely result from limited labor market flexibility - the indicators considered suggest that Croatia has a more rigid labor market than both the SEE and the CEE countries (see below on employment protection legislation; see also Tonin (2005)).

\section{Potential Growth Estimates for the Croatian Economy}

Estimates of potential output growth can be a useful tool in economic policy. They provide a guideline for medium-term growth projections; they are used to estimate a cyclically-neutral budget balance; they can determine if actual growth is driven by temporary factors or by changes in the potential of the economy to grow faster; and they can guide decisions in setting the reform agenda. Moreover, estimates of the output gap, derived from actual and estimated potential output, can indicate inflationary pressures in the economy.

For transition economies, estimates of potential growth are necessarily tentative. Data problems, such as unavailability of some key variables, relatively short time series, measurement issues, and frequent changes in statistical methods can make this task very difficult for most of these economies. Furthermore, the process of structural transformation that has been taking place during the transition period raises questions about the use of historical data to estimate potential growth and, more generally, the use of recent trends to determine future prospects. But with these caveats, almost fifteen years of economic transition in Croatia provides enough information to attempt the empirical exercise of estimating potential growth. Using a number of alternative empirical methodologies to estimate potential growth could partly address some of the above concerns.

This paper uses three methods to estimate Croatia's potential growth:

${ }^{7}$ Hilaire and Ilyina (2007) and Mitra (2007) investigate the main financial risks and vulnerabilities in Croatia.

${ }^{8}$ Pushak, Tiongson and Varoudakis (2007) present empirical evidence of a nonlinear relationship between size of government and economic growth in transition economies. Above a threshold of 35 percent of GDP, they find a negative impact of public spending on growth, though no measurable impact on growth below this threshold.

${ }_{9}$ There is a large literature on the benefits from privatization, particularly in transition economies. Megginson and Netter (2001) review the empirical literature. 
- the Hodrick-Prescott (HP) filter: this is a univariate statistical method that removes short-run fluctuations, resulting in a series whose smoothness is determined by a parameter choice;

- estimation of a production function: this method assumes that Croatia's production function can be approximated by the Cobb-Douglas technology with two-factors, capital and labor, and with constant returns to scale; and

- simulation of a growth empirical model for Croatia: the coefficient estimates from a cross-country growth regression are used to derive Croatia's potential output growth, based on the current values of the growth determinants in Croatia.

The present paper follows earlier efforts to estimate Croatia's potential growth. A wide-ranging study by Mervar and Nestić (1999) featured an early attempt to estimate Croatia's long-run economic growth prospects using a growth regression. On the basis of 1998 data, this study estimated Croatia's long-run annual economic growth rate at 2.4 percent, but suggested this could rise to 4 percent if investment were to rise to 30 percent of GDP. More optimistically, Mihaljek (2001) estimated long-term growth as a function of the rate and efficiency of investment, suggesting that annual growth of 5.4 percent would be realistic for 2001-2013. Subsequently, in a cross-country study of real convergence on EU living standards, Mihaljek (2005) assumed a potential GDP for Croatia of 5 percent from 2003-2010, slowing owing to population decline, to 4.75 percent in 2011-2020, and 4.5 percent in 2021-2030. Vrbanc (2006) estimated potential GDP during 1997-2005 using production functions, though this study focused on elasticities of GDP to labor and capital rather than medium-term prospects.

\section{The Hodrick-Prescott filter}

The Hodrick-Prescott (HP) filter is one of the simplest and most widely used methodologies to estimate potential growth. It is a filter used to obtain a smooth estimate of the long-term trend component of a series. ${ }^{10}$ Real GDP growth data for Croatia start in 1994. To avoid a bias from the latest available data point - the HP filter puts too much weight on recent observations - we extend the series up to 2007, based on World Economic Outlook projections (winter 2007). The filtered and actual time series for real GDP growth in Figure 5 suggest that Croatia has been growing above potential for most of the recent years. The HP filter gives real GDP growth of 4.4 percent for 2006 , which is taken as an estimate of potential growth for Croatia.

\section{Estimating a production function for Croatia}

The following estimates a two-factor production function for Croatia. The production function includes capital and labor:

$$
Y(t)=A(t) F[K(t), L(t)]
$$

where $Y$ is real GDP; $A$ is an index of the level of technology, also called total factor productivity (TFP); $K$ is capital; and $L$ is employment.

${ }^{10}$ Croatia's poor performance on the price liberalization indicator reflects continuing tight control of fuel prices. 
The real growth rate can be decomposed, assuming Cobb-Douglas technology and constant returns to scale, as follows:

$$
\frac{Y}{Y}=\frac{A}{A}+\alpha \frac{K}{K}+(1-\alpha) \frac{L}{L}
$$

where $\alpha$ is the share of rental payments to capital in total income and (1- $\alpha)$ is the share of wage payments to labor in total income, assuming competitive product markets. ${ }^{11}$

We estimate the above equation for Croatia. All data sources, including for employment, are from the IMF World Economic Outlook (WEO, Winter 2007), except the data for average wages, which are from the Croatian National Bank (CNB), and historical data for the capital stock, for which we use two alternative series. ${ }^{12}$ The first consists of estimates provided by the CNB for the period 1994-2005 using the perpetual inventory method. The second is based on direct calculations of capital stock by sector for the period 1999-2003, provided by the Croatian Central Bureau of Statistics (CROSTAT). For the years before and after these periods, the capital stock is estimated based on the perpetualinventory method, using WEO data for investment and assuming a rate of capital depreciation of 2.7 percent, which is the estimate used by CROSTAT. Although measuring the capital stock directly may be preferable to estimates using the perpetual-inventory method, the CROSTAT data are still preliminary and may change. Therefore, the discussion that follows addresses results from both methodologies.

The estimates require several further assumptions. Croatia's employment income share is calculated as the ratio of the total wage bill (average wage times total employment) over nominal GDP. For future years, Croatia's average wage is assumed to grow by 6 percent, which is equal to its average growth in recent years. This gives an employment income share of about $0.47-0.51$, depending on the year. Based on the constant returns to scale assumption, the capital income share is one minus the employment income share, or 0.49-0.53. ${ }^{13}$ The TFP growth is equal to the residual after actual growth of output, capital and employment are included in equation 2 for the period up to 2006. For years after 2006, we assume that the current TFP trend growth, estimated using an HP filter, continues.

The production function-based estimates in Table 1 suggest that Croatia's potential growth is between 4.3 and 4.4 percent. The estimates suggest that the growth of Croatian output has been primarily driven by capital accumulation, with only a limited contribution from TFP growth in recent years and even less from employment. To some extent, this is not surprising. Croatia was newly independent and a new market economy in the aftermath of a war. Infrastructure investment and rebuilding regions that were destroyed during the war should have led to a high growth contribution of capital during the 1990s. Indeed, as noted in Section I, the share of public investment in GDP has been much higher in Croatia than in other transition economies. In more recent years, privatization and high interest from domestic and foreign investors is also expected to have contributed to growth, although Croatia's private investment share in GDP is not as high as in more ad-

${ }^{11}$ For details, see Hodrick and Prescott (1997).

${ }^{12}$ For more details, see Barro and Sala-í-Martin (2004).

${ }^{13}$ Capital stock data for transition economies are usually less reliable than for advanced economies due to short time series. Therefore, the use of alternative estimates, when available, is highly recommended. 
D. Moore, A. Vamvakidis: Economic growth in Croatia: potential and constraints Financial Theory and Practice 32 (1) 1-28 (2008)

Table 1. GDP Growth and Contributions: Estimates from a Production Function for Croatia

\begin{tabular}{lrrr}
\hline & $1996-2001$ & $2002-2005$ & $2006-2009$ \\
\hline Using CNB capital stock estimates & & & \\
\hline Real GDP growth & 3.6 & 4.7 & 4.4 \\
\hline Contributions: & & & \\
\hline Capital & 3.2 & 2.7 & 2.8 \\
\hline Labor & -1.0 & 0.9 & 0.5 \\
\hline Productivity & 1.5 & 1.1 & 1.1 \\
\hline Using CROSTAT capital stock estimates & & & \\
\hline Real GDP growth & 3.6 & 4.7 & 4.3 \\
\hline Contributions: & & & \\
\hline Capital & 1.5 & 2.2 & 2.2 \\
\hline$\quad$ Labor & -1.0 & 0.9 & 0.5 \\
\hline$\quad$ Productivity & 3.2 & 1.6 & 1.6 \\
\hline
\end{tabular}

Source: authors' calculation

vanced transition economies (see Part B, and Appendix). The estimates that use the CROSTAT capital stock suggest a somewhat higher contribution from TFP growth, in particular during the 1990s, but a slightly lower potential growth.

Persistently high unemployment rates and relatively low labor participation rates lead to a very limited contribution of employment to growth in Croatia. Reforms introduced in 2003 to increase labor market flexibility may have led to the small positive contribution of labor to growth in recent years, from a negative contribution in the late 1990s. Based on the above estimates, if a period of fast employment growth allowed Croatia to reduce the unemployment rate from the present 11 percent to say 8 percent over the next three years, the temporarily higher employment contribution would boost annual potential growth to 4.8 percent over this period.

\section{Estimating and Simulating a Growth Model for Croatia}

This section estimates an econometric growth model based on a large cross-country sample. The estimates use a sample of a 109 developed and developing economies over the period 1996-2005. ${ }^{14}$ The estimated coefficients are then used to forecast Croatia's potential growth based on the current values of the independent variables in Croatia. All data sources are as indicated in the Appendix table. The empirical specification is the following:

$$
\text { (Real GDP per capita growth) }_{i}=c+\beta X_{i}+u, \quad \text { for country } i=1, \ldots, n
$$

The dependent variable is the average per capita real GDP growth rate for each country $\boldsymbol{i} ; \boldsymbol{c}$ is the constant term; $\beta$ is the matrix of parameters to be estimated; $X_{i}$ is the matrix of independent variables; and $u$ is the error term. Each country has one observation,

${ }^{14}$ Using estimates from the literature for the income share of labor in other emerging markets leads to similar results. 
which is either the average over 10 years or the initial value in 1996, depending on the variable. Focusing on the last ten years has a number of advantages: the sample includes transition economies; some cross-country indices are not available for earlier years; and overall data quality has improved compared to previous years.

Causality can be difficult to determine in growth regressions. ${ }^{15}$ Even though estimation with instrumental variables has confirmed the robustness of most of the above growth determinants, one has to be cautious and interpret the estimates as broad correlations, which indicate an interaction with growth that may be going both ways.

Our preferred specification captures the most important, but not all, determinants of growth. We estimated a large number of empirical specifications based on different combinations of the growth determinants that were discussed above. We selected our preferred specification by including only variables that turned out to be statistically significant and robust to changes in the specification. This does not imply that the omitted variables do not affect growth, since almost all of these variables were statistically significant in some empirical specifications. Since some of these variables are alternative measures of similar aspects of the economy and are highly correlated, one has to choose those that seem to explain growth the most.

The estimated equation is:

\begin{tabular}{lc} 
Dependent variable & Real GDP per capita growth \\
\hline constant & $0.98(0.62)$ \\
dummy for SEE and CEE & $+1.88(2.71)$ \\
initial real GDP per capita & $-0.49(-3.62)$ \\
population growth & $-0.43(-1.78)$ \\
investment/GDP & $+0.14(3.58)$ \\
inflation rate & $-0.02(-2.29)$ \\
credit to private sector/GDP & $+0.001(3.18)$ \\
index of economic freedom & $+0.43(2.30)$ \\
cost of business start-up procedures & $-0.03(-3.85)$ \\
(\% of GNI per capita) & \\
\hline
\end{tabular}

number of observations: 109; R²: 0.56; adjusted R²: 0.52; F-statistic: 15.80 heteroskedasticity consistent estimates in parenthesis.

The results are consistent with the discussion in Section I. Keeping everything else constant, countries with a relatively low income level, a low population growth rate (a low dependency ratio), a high investment share, a low inflation rate, and a relatively developed financial sector (measured by the ratio of private sector credit to GDP) grow faster. Both macroeconomic and structural policies affect economic growth. The index of economic freedom, which measures a number of different aspects of macroeconomic and structural policies and reforms, has a positive and statistically significant estimate. ${ }^{16}$ Moreover, countries with high costs for starting new businesses grow more slowly. Variables measuring aspects of fiscal policy enter the regression through the index of economic freedom.

${ }^{15}$ The sample size is determined by data availability.

${ }^{16}$ See for example Temple (2000). 
Although such variables - fiscal deficit, or government consumption - have been found to affect growth negatively by a number of the studies referred to above, the chosen specification seems to explain cross-country growth differences better, at least for this period. The FDI-to-GDP ratio has a positive and statistically significant estimated coefficient, but only when the cost of business start-up procedures is not included in the regression. ${ }^{17}$ This is because of collinearity, since countries with low costs for starting a new business attract more FDI as a result.

The regression also includes a separate constant term for the SEE (including Croatia) and the CEE transition economies. We tried a number of country dummies, but this was the only one which turned out statistically significant. Dummy variables for Africa and for East Asia, although statistically significant in growth regressions for earlier decades, with negative and positive estimates respectively, do not turn out significant in this specification. The significance of the dummy variable for the SEE and the CEE transition economies suggest that they have been growing faster than what would have been expected based on the growth determinants in this model - by 1.9 percent in terms of per capita GDP. Most of these economies collapsed in the beginning of their transition during the early 1990s, while some experienced social unrest, or, as in the case of Croatia, war. However, this was followed by a strong economic recovery after the mid-1990s, as peace prevailed, the transition process moved forward, and the region's economies opened up to the rest of the world. The result may have been a growth "bonus", which, however, may not continue in the future, at least not to the same extent.

The scope for "catch-up" economic growth depends on where Croatia stands in the transition process. Using the above estimates and the latest values of the independent variables for Croatia, as indicated in the Appendix, gives estimates for Croatia's potential growth. The simulations imply that Croatia's potential growth would be 5.1 percent (in terms of both real GDP and real GDP per capita terms). However, assuming that the growth "bonus" from transition will not continue to the same extent in the years ahead changes this estimate to a potential growth of 4.2 percent, if the growth "bonus" is reduced by half, or to 3.2 percent, if it is eliminated completely. Since the transition process is still under way, the mid-estimate of 4.2 percent seems to be a more reliable potential growth estimate for Croatia.

This growth model can help forecast the impact of reforms on Croatia's economic growth. Using the potential growth estimate of 4.2 percent as the starting point, we focus on the impact of changes in the economic freedom index and in the cost of starting a new business, which are areas in which Croatia lags behind the CEE and the euro area. If the values of these two variables in Croatia were to reach the average levels in the CEE through economic and structural reforms, the simulation of the above growth model suggests that Croatia's potential growth would increase to 4.6 percent. If they were to reach the average value in the euro area, Croatia's potential growth would increase to 4.7 percent. Finally, if they were to reach the level in Ireland, which has been one of the bolder refor-

${ }^{17}$ The index of economic freedom is an average of a large number of sub-indices, which are grouped as follows (see also Appendix table): size of government, legal system and property rights, sound money, freedom to trade internationally, and regulation. For more details, definitions, and the list of indices within the above groups, see http:// www.freetheworld.com/ 
mers and stronger performers during recent years in Europe, Croatia's potential growth would increase to 5 percent. To the extent that accelerated reforms promote higher levels of FDI, especially greenfield FDI, potential growth could rise farther - though quantifying such a pickup would be beyond the scope of the model.

\section{Constraints on Growth: A “Growth Diagnostic” Approach}

The growth diagnostic approach seeks to identify binding constraints on growth. This approach, proposed by Hausmann, Rodrik and Velasco (2005), stresses the need to prioritize policies to target the binding constraints, as opposed to pursuing a laundry list of "good" policies that fail to address the constraints. ${ }^{18}$ The decision tree below (text chart) shows where to look for the possible factors holding back private investment and economic growth.

A process of elimination can help identify binding versus nonbinding constraints. The starting point is to determine whether growth is being inhibited by low returns to activity (left-hand side of the tree) or high costs of finance (right-hand side). For Croatia, we can quickly exclude the factors on the right-hand side of the decision tree:

- International finance. Croatia has enjoyed ample access to international finance, evident from the increase in external debt over the past several years. Moreover, Croatian bond spreads - already low by regional standards - fell to historically low levels in 2006-2007. If anything, this ease of access has itself had indirect costs by easing the urgency of structural reforms. ${ }^{19}$

- Local finance. Domestic saving is ample and financial intermediation strong.

- Gross national saving averaged nearly 24 percent of GDP through 2002-2006, high by regional standards (of CEE and SEE countries, only Slovenia had a higher saving ratio).

- Turning to intermediation: Šonje (1999) emphasized the link between financial depth and economic growth and, in the Croatian context, the importance of a stable banking system. Subsequently, Vujčić and Lang (2002) argue that the rehabilitation of the banking sector and the entry of foreign banks in the late 1990s means that the sector is now supporting rather than inhibiting growth. Bank credit to the private sector was 72 percent of GDP as at end-2006; rapid credit growth (also in the nonbank sector) and steadily falling bank lending interest rates also suggest strongly that the barriers to growth are now elsewhere.

The analysis thus focuses in more detail on low returns to economic activity (lefthand side of the tree). The low-returns hypothesis is consistent with the earlier observations that overall investment is high by regional standards; private investment and real GDP growth slightly below average; and export performance significantly below average. It is also consistent with relatively low levels of FDI, since foreign investors are much less

\footnotetext{
${ }^{18}$ These results are available from the authors.

${ }^{19}$ Recent practical applications of this methodology elsewhere (and the identified constraints on growth) include Bolivia (political and social instability; see World Bank, 2005), Morocco (government and market failures that inhibit product diversification; World Bank, 2006), Thailand (lack of skilled labor; Richter, 2006), and Lebanon (fiscal imbalances and barriers to entry; Berthélemy, Dessus and Nahas, 2007).
} 
Figure 1 Growth Diagnostics: Identifying the Constraints

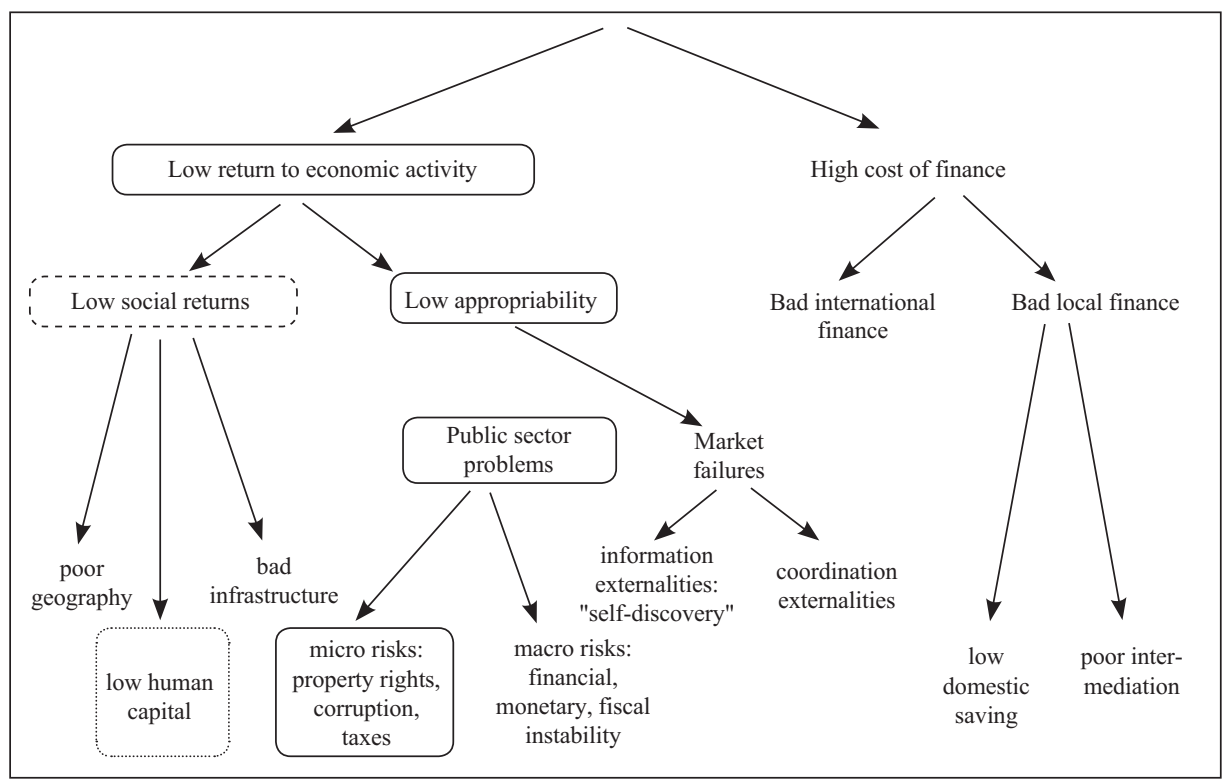

Source: Adapted from Hausmann, Rodrik and Velasco (2005).

likely than local entrepreneurs to be financially constrained. The next step is to consider whether the problem is low social returns (that is, low total economic returns on factor accumulation, regardless of their ultimate recipient), or low "appropriability", i.e., low private returns even if social returns are high (for example, because of taxes, corruption, market failures, or some other cause).

Low social returns - stemming from human capital problems - are one candidate explanation. Three factors can explain low social returns, though the first two can be readily ruled out for Croatia:

- Geography. Croatia's location gives it ready access to central, Mediterranean and southeastern Europe; and its long (and beautiful) coastline underpins the vital tourism industry (tourist receipts account for over 20 percent of GDP).

- Infrastructure. Croatia's infrastructure compares favorably by regional standards (Figure 6), and EBRD indicators also point to progress in infrastructure reform. Indeed, public expenditure on infrastructure has been high in Croatia: for example, spending on highway construction (investment spending by the HAC and HC road funds) averaged nearly $2 \frac{1}{2}$ percent of GDP over 2002-2006. Thus, infrastructure does not appear to be constraining growth.

- Human capital. Although education and literacy levels are in line with regional standards, the Institute for Public Finance (2004) finds that "employees in the Republic of Croatia do not have the skills, knowledge, and abilities necessary to develop globally 
competitive products and to compete in the European Union." Moreover, as noted earlier, labor force participation rates are very low and have dropped for both men and women over the past five years, contributing to the Lisbon Council's European Human Capital Index ranking Croatia last among 12 central and eastern European countries. ${ }^{20}$

A lack of skilled human capital could be a constraint on growth. In principle, low activity rates could reflect low demand for labor. However, Šošić (2004) finds that the return on investment in education - rising from 7.6 percent in 1996 to 10.5 percent in 2002 - is significantly above western and central European levels (around 6.5 percent). High returns to education, especially given their recent increase, are consistent with the hypothesis that a limited supply of educated workers is constraining economic growth.

Low appropriability also cannot be ruled out as a growth constraint for Croatia. The growth diagnostic approach divides the possible causes between market failures and public sector problems and inefficiencies.

Reasonable levels of innovation in Croatia suggest that market failures in the form of information externalities are unlikely to be the main problem:

- The diversification of Croatia's export base does not seem out of line with peer countries. Klinger and Lederman (2006) report cases of export "discoveries" or "inside-the frontier innovations" during 1997-2002 for 73 countries: Croatia ranked a respectable $23^{\text {rd }}$ in terms of number of discoveries. ${ }^{21}$ Croatia also performs satisfactorily by regional standards (Table 2).

- Innovation - measured by new patents - is also broadly in line with peer countries (Table 3), especially taking population size into account, albeit well behind the regional leaders Hungary and Slovenia.

- But room for improvement remains. In the World Economic Forum's most recent Global Competitiveness Report (World Economic Forum, 2006), one of Croatia's weakest rankings was on FDI as a source of new technology - a consequence of the limited inflows of greenfield FDI.

The public sector is not generating "macro risks" that obviously constrain growth. "Financial/monetary" risks are low: indeed the CNB has successfully maintained broad exchange rate stability and delivered consistently low inflation since the mid-1990s. And following the significant fiscal consolidation since 2004, Croatia would meet - or at least is within striking distance of - the Maastricht deficit and debt criteria. However, public debt is high by regional standards, even if below the euro area average. While external vulnerabilities and the need to ensure debt sustainability are powerful arguments for furt-

${ }^{20}$ Vamvakidis (2007) presents empirical evidence for a panel of developing and emerging economies suggesting that countries that borrow more adopt macroeconomic and structural reforms at a slower pace and, therefore, have slower economic growth. Theoretical considerations suggest that borrowing abroad makes the status quo easier to bear. A simulation of the empirical model for Croatia suggests that if Croatia's external debt-to-GDP ratio had remained stable during 2001-2005 (instead of rising by 19 percentage points), then Croatia's ranking for the index of economic freedom, which the paper uses to measure progress in reforms, would have been 65 out of 123 economies, instead of 76 , all else being constant. The estimates thus imply that eleven countries reformed faster than Croatia during this period, simply because Croatia's increase in external indebtedness reduced pressures for economic reforms.

${ }^{21}$ Although this study ranked Croatia in the middle of the 12 countries for human capital endowment (i.e., education and training) and human capital productivity, Croatia's utilization of human capital was very low, dragging down its overall ranking. See Ederer, Schuller and Willms (2007). 
Table 2. Croatia and Selected European Countries: Identified Cases of "Inside-TheFrontier" Innovation, 1997-2002

\begin{tabular}{lrlr}
\hline Poland & 221 & Moldova & 33 \\
Romania & 114 & Turkey & 30 \\
Hungary & 90 & Portugal & 27 \\
Latvia & 68 & Cyprus & 26 \\
Estonia & 53 & Slovak Republic & 22 \\
Croatia & 47 & Czech Republic & 8 \\
Greece & 46 & Italy & 5 \\
Slovenia & 43 & Spain & 5 \\
Macedonia, FYR & 42 & & \\
\hline
\end{tabular}

Source: Klinger and Lederman (2006).

Table 3. Innovation in Croatia and Selected European Countries: Patents Granted in United States and Europe

\begin{tabular}{lccc}
\hline & US Patent and Trademark Office & European PO \\
& $1993-2000$ & $2001-2005$ & 2005 \\
\hline Albania & 1 & 0 & 0 \\
Bulgaria & 20 & 21 & 5 \\
Bosnia and Herzegovina & 0 & 2 & 0 \\
Czech Republic & 81 & 141 & 26 \\
Estonia & 8 & 15 & 3 \\
Croatia & 58 & 54 & 9 \\
Hungary & 350 & 274 & 32 \\
Lithuania & 7 & 11 & 1 \\
Latvia & 5 & 9 & 0 \\
Macedonia, FYR & 0 & 1 & 0 \\
Poland & 97 & 83 & 15 \\
Romania & 22 & 36 & 20 \\
Slovak Republic & 15 & 20 & 10 \\
Slovenia & 74 & 88 & 24 \\
\hline
\end{tabular}

Sources: U.S. Patent and Trademark Office; European Patent Office.

her fiscal consolidation, the fiscal stance is not a direct and immediate constraint on economic growth.

However, the weak business environment suggests that "micro risks" from the public sector are impeding growth significantly. Notwithstanding recent reforms, survey evidence consistently ranks Croatia's business environment below the average of its peers in 
CEE countries and the euro area (Figure 4), though the picture is mixed compared with the SEE countries.22 The World Bank's 2006 Doing Business survey finds that it costs more and takes longer to start a new business and to register property in Croatia. Furthermore, Croatia's legal system, based on indicators for property rights, contract enforcement, and corruption, does not compare well with the legal systems in the CEE and in the euro area (Appendix). Relatedly, the World Economic Forum Global Competitiveness Report for several years has persistently identified inefficient government bureaucracy as the most problematic factor for doing business. In the context of the growth diagnostic, these findings are consistent with growth being constrained by public sector "micro risks": problems with property rights; problems stemming from the large size of government, including inefficient bureaucracy and the high regulatory burden; and corruption.

Looking more closely at these "micro risks", property rights and red tape are particular problem areas.

- Property rights and contract enforcement. Although the Doing Business survey ranks Croatia favorably on contract enforcement - with the number of procedures required to enforce contracts being in line with the OECD average - contract enforcement remains slow. According to the European Commission (2006): "The judicial system has continued to suffer from slow and inefficient court proceedings, poor case management and low administrative and professional capacity. These circumstances may discourage economic actors from taking cases to court and undermine an effective enforcement of creditor and property rights."

- Administrative and regulatory burden. Although measures are under way at the central government level, problems at the local level remain. The latest IMF country report notes that investors often face uncertainties and delays in obtaining necessary permits and numerous and nontransparent fees, with complex local government regulations seen as conducive to corruption. ${ }^{23}$ In addition, employment protection legislation (EPL) is strict. Tonin (2005) calculates the OECD indices of the strictness of EPL for several central and eastern European (non-OECD) countries: Croatia has the second-strictest EPL in the sample, and is also high by OECD standards. EPL is especially strict for temporary workers (Figure 7). The EPL is successful in protecting jobs for existing employees (insiders), but constitutes a severe disincentive to new job creation (see also OECD, 2006).

${ }^{22}$ Using 6-digit data from the UN COMTRADE database, Klinger and Lederman define a "discovery" as an export good that the country did not previously export (in a base period of 1994-1996).

${ }^{23}$ In response to weaknesses in the business environment, the Croatian government has recently taken several steps to simplify procedures at the central government level: the hitro.hr service launched in 2005 introduced a "onestop shop" to establish a business and provides a platform for a variety of "e-government" services; the Trade and Investment Promotion Agency was established in late 2005 to assist foreign investors; a working group (with USAID assistance) is preparing a "regulatory guillotine" to propose elimination of obsolete and/or unnecessary regulations and issued its initial recommendations in mid-2007; a project was launched in 2002 (with World Bank and EU assistance) to improve the land cadastre and registry system to cut delays in the process of registering land and buildings (see http://www.zikprojekt.hr); the number of pending land registration cases has been cut from 339.000 at end-2003 to 215.000 at end-2005 (land registry data was published on the internet in May 2005); and the government established "entrepreneurial zones" on land free of ownership uncertainty to provide businesses with space, infrastructure and easier administrative procedures (in line with EU rules, the zones do not provide any tax incentives). For more details, see Government of the Republic of Croatia (2006). 
- Corruption. According to Transparency International's corruption perceptions index (CPI; Figure 8), Croatia suffers from "serious", though not "severe", levels of corruption. ${ }^{24}$ The WEF (2006) Global Competitiveness Report corroborates this finding. However, Demekas, Horváth et al. (2005) find no direct evidence that corruption has dampened FDI in SEE countries, though they note that efforts to combat corruption could still stimulate foreign investment indirectly.

- Tax burden. The evidence here is mixed. Croatia's corporate income tax rate of 20 percent is broadly in line with the CEE average. A 2006 study by the Economics Institute of Zagreb ${ }^{25}$ estimated "forward-looking" effective average tax rates on investment for 20 countries, concluding that Croatia's tax burden is favorable and needs to be better communicated to potential foreign investors. This would suggest that the corporate income tax burden is unlikely to be the binding constraint on growth, or at least on foreign investment. On the other hand, respondents to the Global Competitiveness Report cite the tax burden as the third most important problem for doing business in Croatia (behind inefficient government bureaucracy and corruption). Moreover, as in several other countries in the region, social security contribution rates (totaling 37 percent of gross earnings) are high. ${ }^{26}$

In sum, the growth diagnostic indicates that public sector-related micro risks are the most important binding constraint on growth, because of their impact on the business environment. This is consistent with the results from the previous section. The diagnostic also points to human capital problems as an additional constraint on growth.

\section{Conclusion}

The estimate for potential economic growth of $4-4 \frac{1}{2}$ percent over the medium term is robust to different methodologies. The Hodrick-Prescott, production function and growth regression methodologies yield very similar overall results. In the short term, Croatia's growth rate may well exceed its estimated potential, but the results in this paper suggest that growth rates significantly above $4-4 \frac{1}{2}$ percent cannot be sustained for long without further progress in economic reforms that will increase productivity growth and attract greenfield FDI.

The cross-country comparisons of growth determinants and the estimates from the growth regression suggest areas where economic reforms are needed to increase Croatia's potential growth. Reducing the role of the state in the economy through fiscal consolidation and privatization would help enhance market competition and support private sector activity. Moreover, it would contribute to macroeconomic stability by mitigating convergence-related demand pressures and insuring against external vulnerabilities. Structural reforms to create a business-friendly environment by facilitating the start-up of new businesses, creating an efficient bureaucracy, increasing labor market flexibility, and refor-

\footnotetext{
${ }^{24} \mathrm{http}: / /$ www. imf.org/external/pubs/cat/longres.cfm?sk=20473.0

${ }^{25}$ Transparency International categorizes corruption as "serious" for a CPI score below 5 and as "severe" for a CPI score below 3 .

${ }^{26}$ An English-language summary of the study is available at: http://www.eizg.hr/AdminLite/FCKeditor/UserFiles/File/summary-etr.pdf
} 
ming the judiciary would allow Croatia to experience growth rates closer to those observed in peer countries. The estimates also suggest that, without faster progress in these reforms, the Croatian economy could grow more slowly than in the recent past as the growth "bonus" from transition diminishes.

The growth diagnostic reinforces the importance of improving the business environment. The diagnostic approach indicates that the important constraints on growth reflect neither financing problems nor a lack of ideas for investment. Rather, Croatia is not yet as good a place to do business as it could be, even allowing for recent improvements. Moreover, the diagnostic suggests that measures in other areas expected to be conducive

Figure 1 Growth and Trade: Croatia and Selected European Countries Geometric real growth rates, 2002-2006

Real GDP

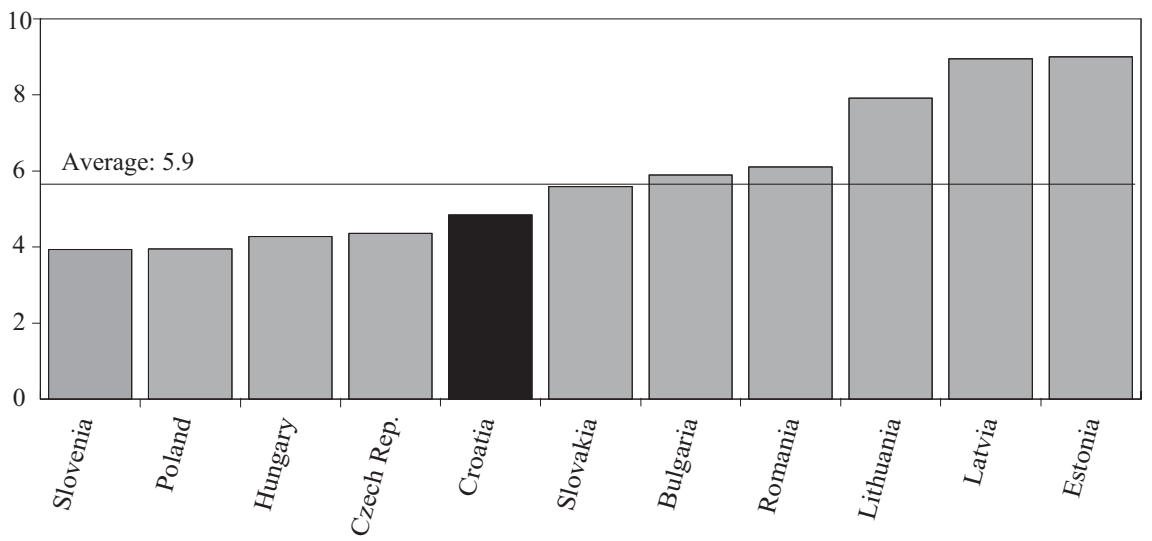

Exports of goods and services

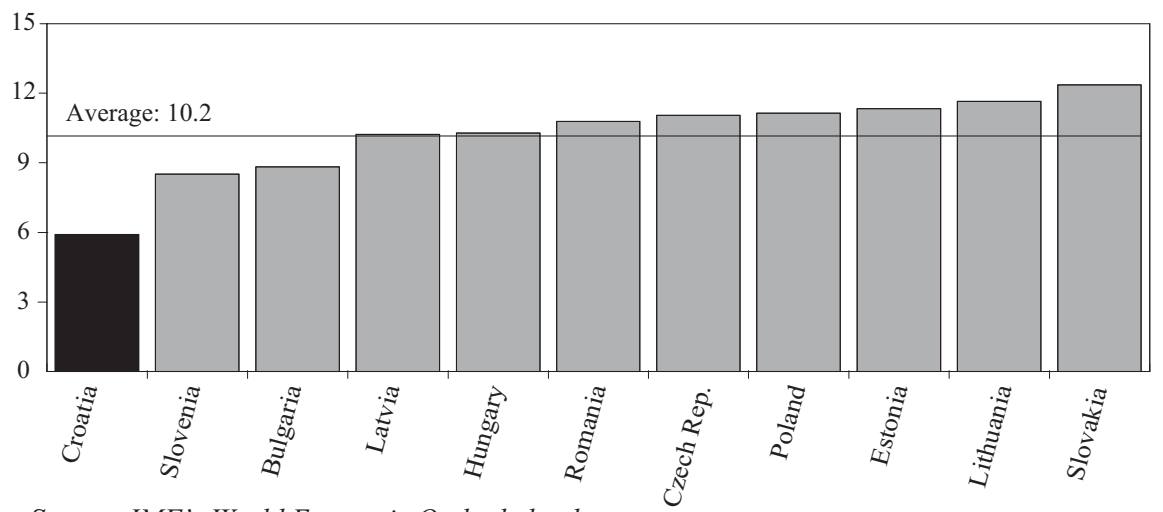

Source: IMF's World Economic Outlook database. 
Figure 2 Croatia and Selected European Countries: Foreign Direct Investment, 2002-2005

(Average 2002-2005, in percent of GDP)

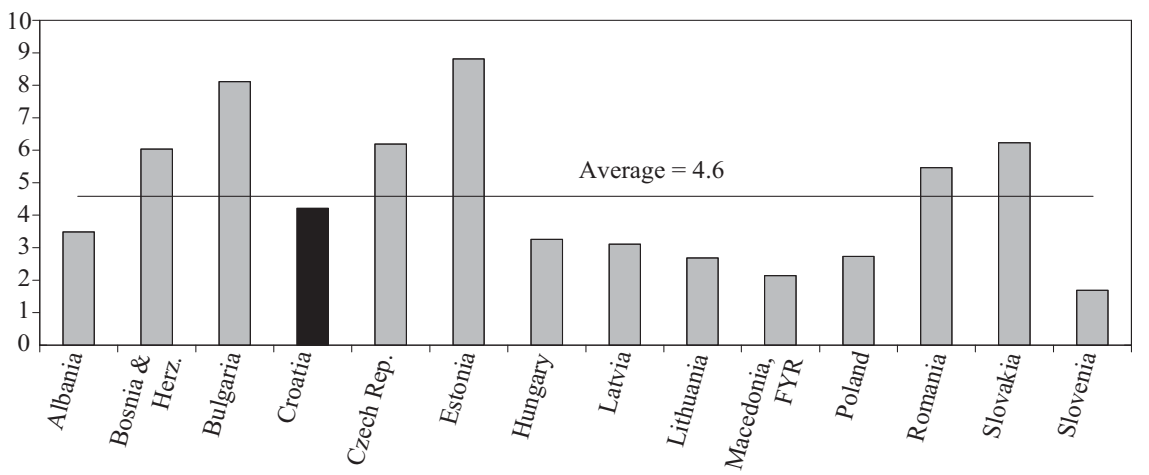

Source: IMF World Economic Outlook database.

(Number of greenfield FDI projects, total, 2002-2005) ${ }^{a}$

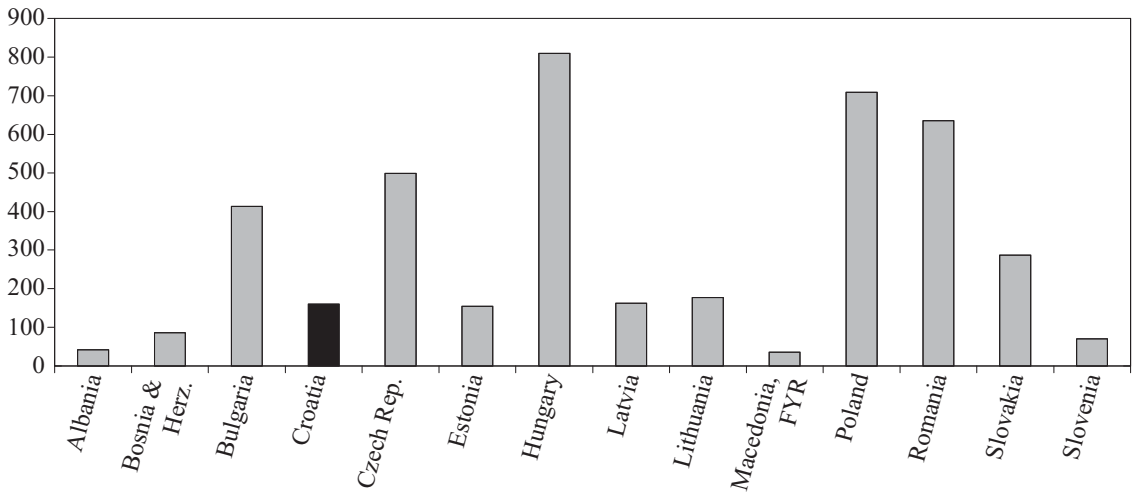

a These data should be interpreted cautiously in the absence of comparable data on the size of projects Source: UNCTAD World Investment Report 2006.

(Number of greenfield FDI projects divided by population size, 2002-2005)

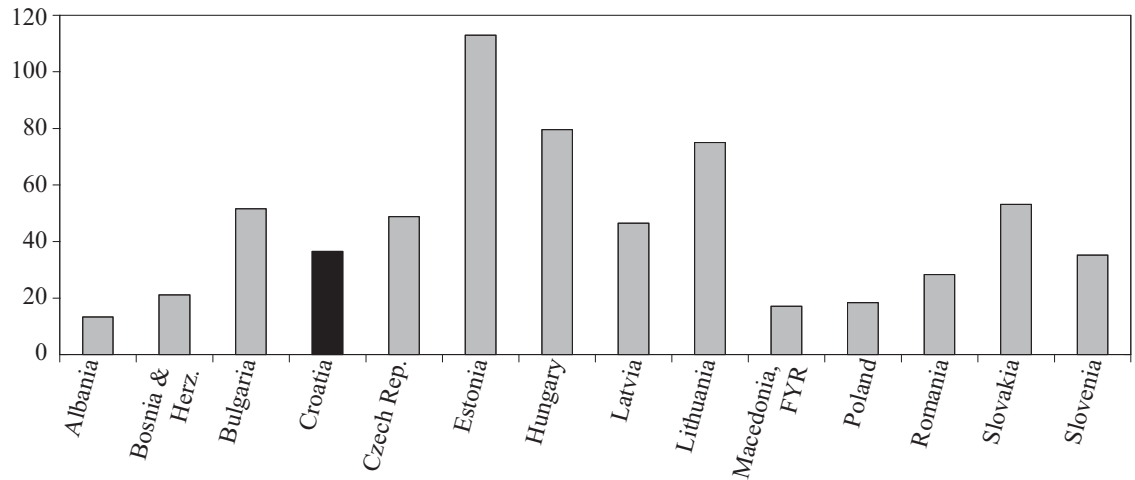

Source: UNCTAD; and authors' calculations (population data from IMF World Economic Outlook database). 
Figure 3 EBRD Average Transition Indicator, 2006

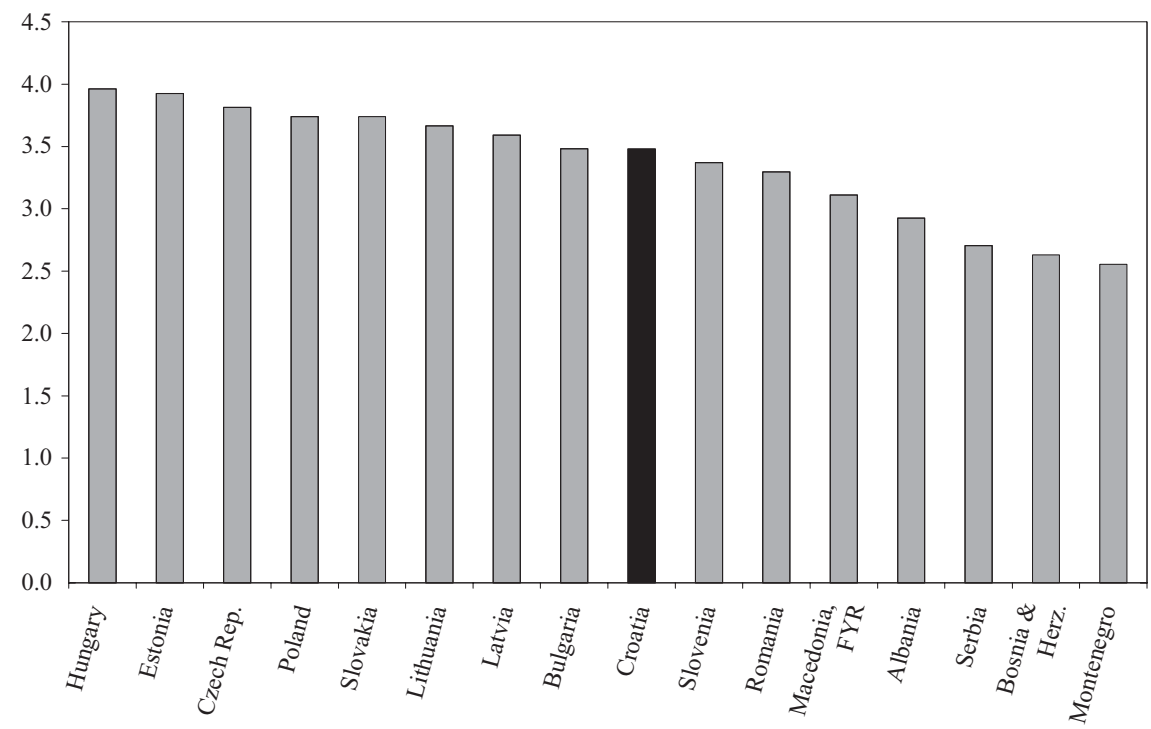

Source: European Bank for Reconstruction and Development.

Figure 4 Croatia and Selected European Countries: Business Environment, 2005-2006

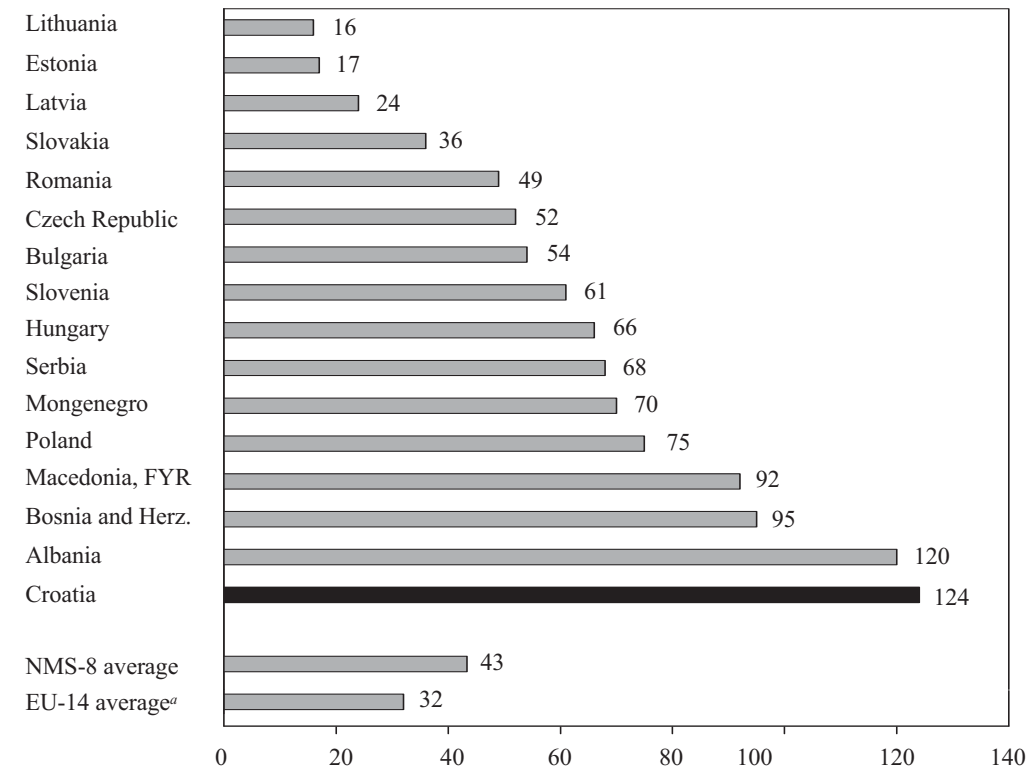




\section{Estonia}

Czech Republic

Slovenia

Latvia

Slovakia

Lithuania

Hungary

Poland

Croatia

Romania

Bulgaria

Macedonia, FYR

Serbia and Mont.

Bosnia and Herz.

Albania

NMS-8 average

EU-14 ${ }^{a}$ average

Estonia

Czech. Republic

Slovenia

Hungary

Slovakia

Lithuania

Latvia

Poland

Croatia

Romania

Bulgaria

Macedonia, FYR

Serbia and Mont.

Bosnia and Herz.

Albania

NMS-8 average

EU-14 average
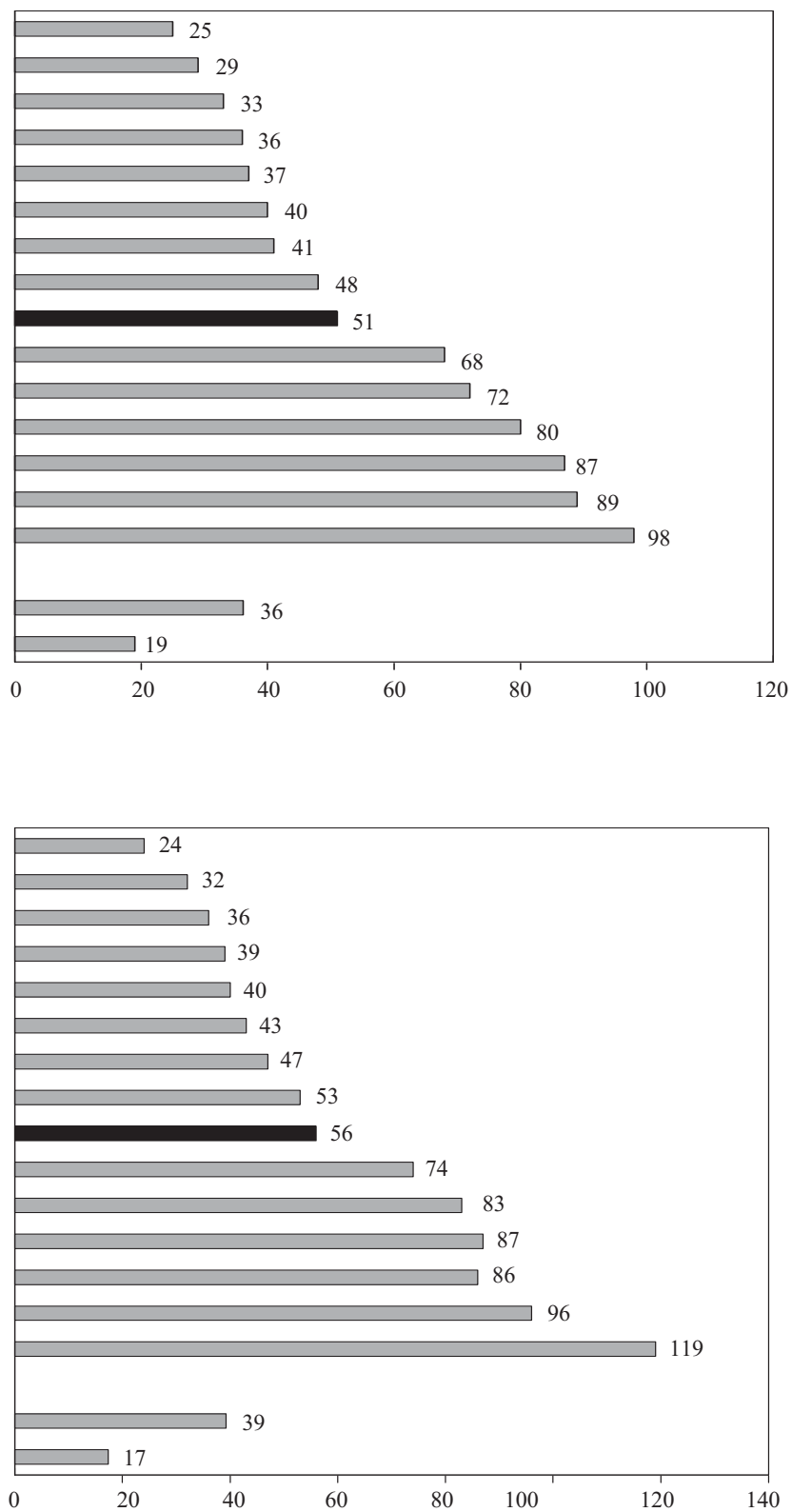


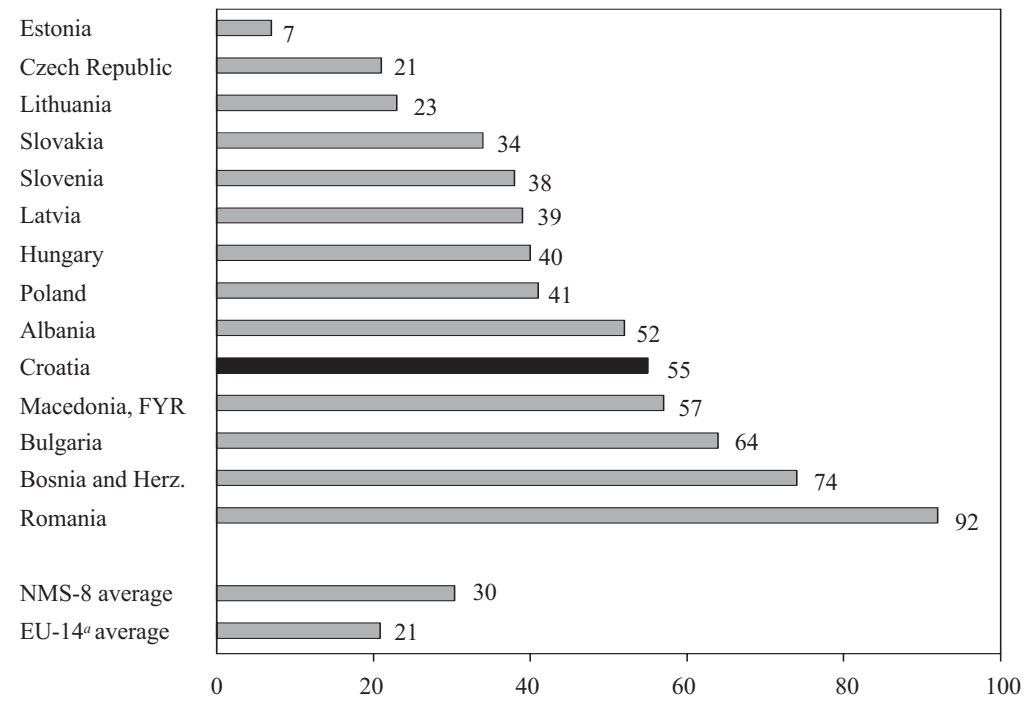

a No ranking available for Luxembourg.

Sources: World Bank; World Economic Forum; Heritage Foundation.

Figure 5 Croatia: Real GDP Growth and Hodrick-Prescott Filter, 1995-2006

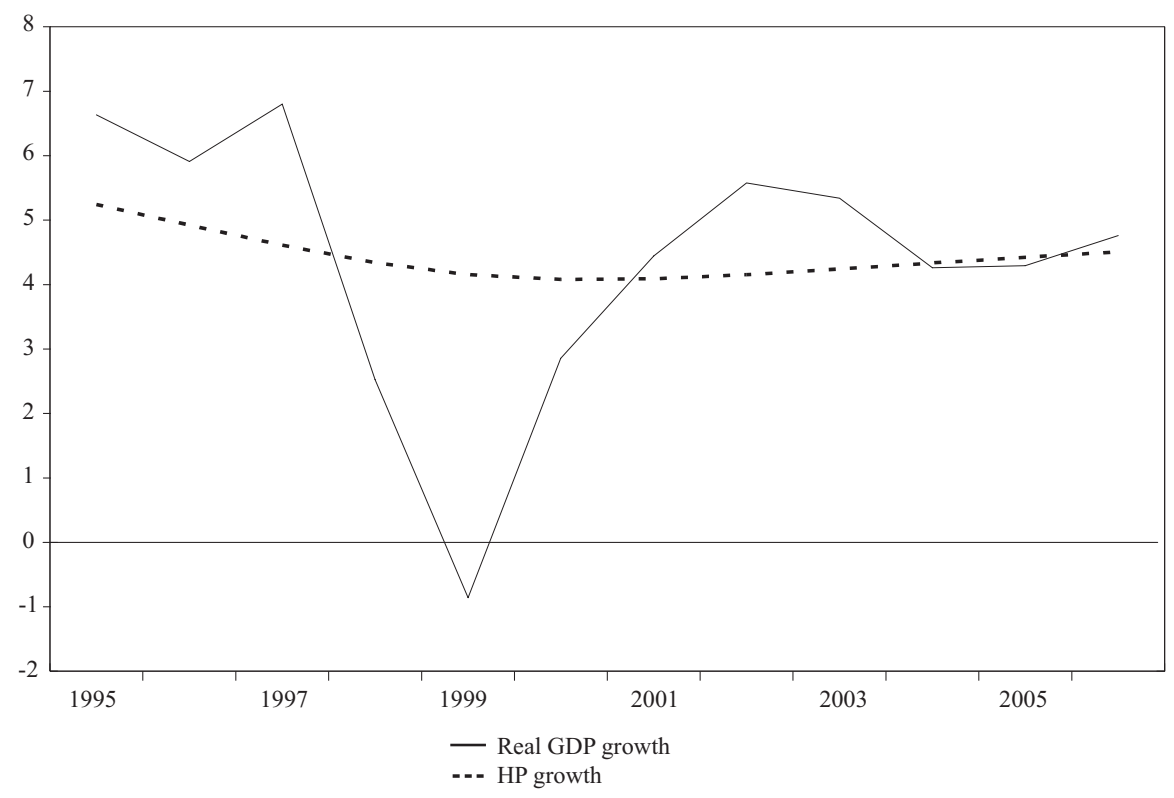

Source: authors 
Figure 6 Croatia and Selected European Countries: Infrastructure

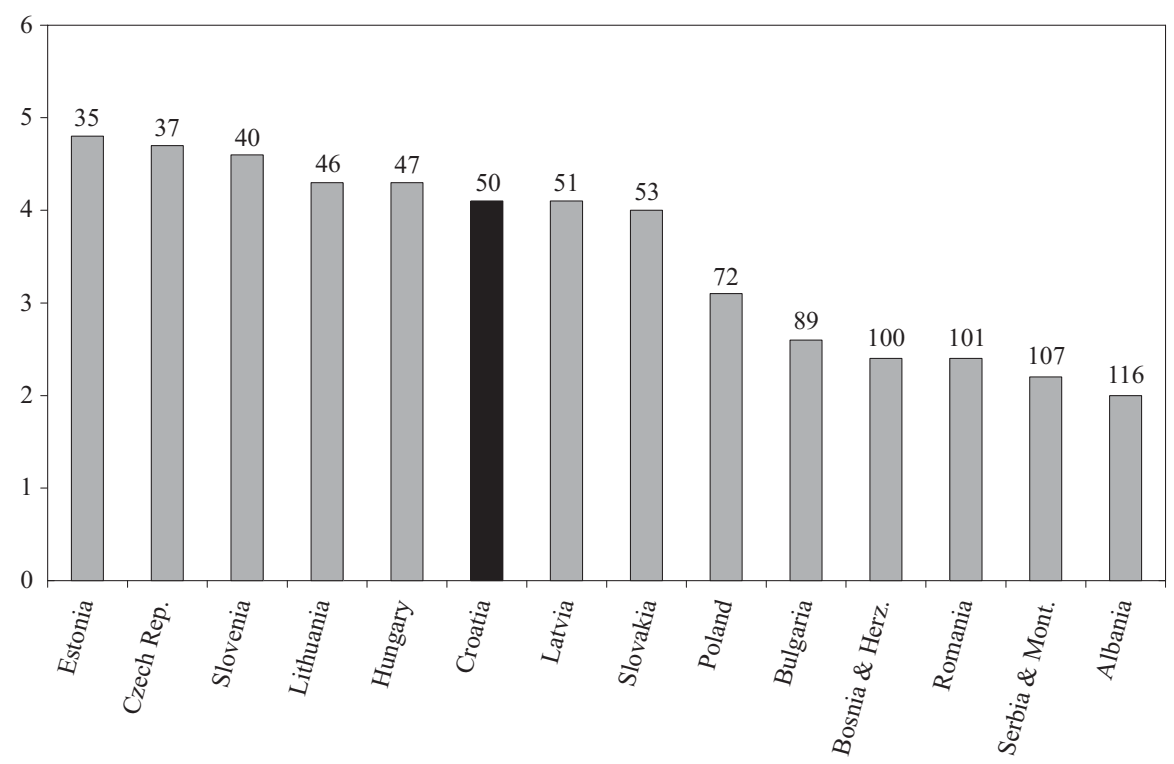

Source: WEF Global Competitiveness Report 2006-2007.

Figure 7 Employment Protection Legislation, 2003-2004

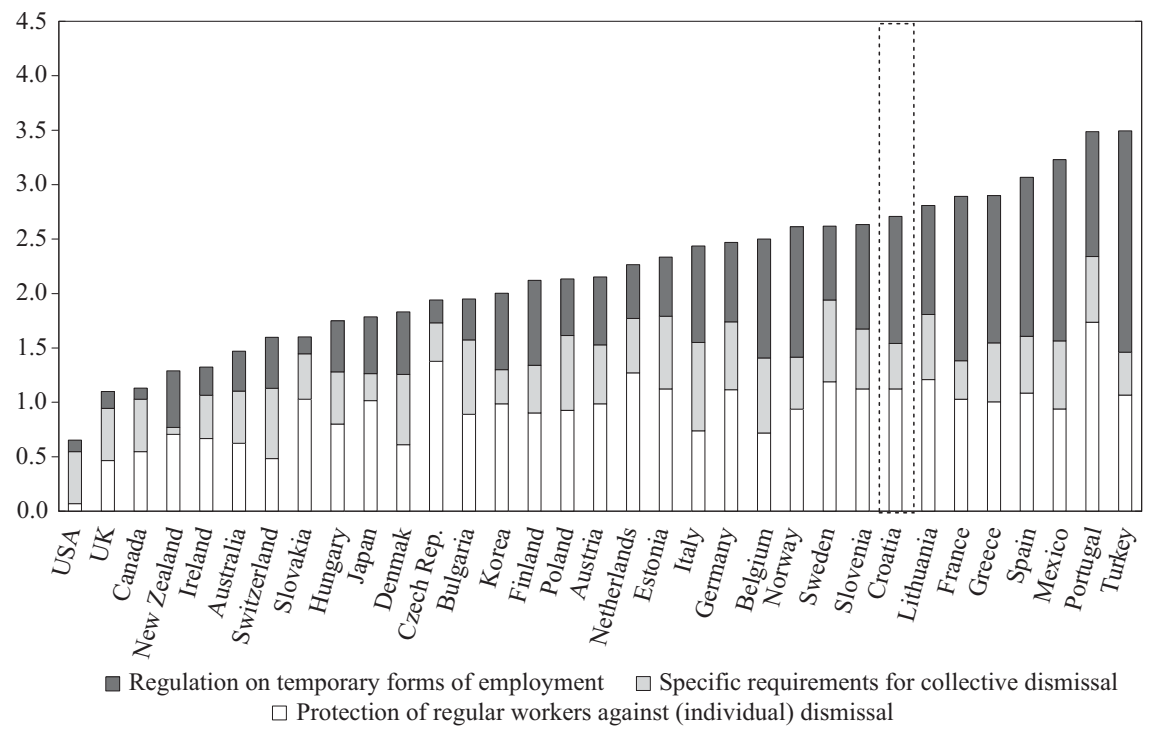

Note: For Bulgaria, Estonia, Lithuania and Slovenia, also see Tonin (2005) baed on legislation as at 2004. For OECD countries, see OECD (2006), Figure 3.9; data refer to 2003.

Sources: for Croatia, Tonin (2005) based on the Labor Act as amended up to September 21, 2004. 
Figure 8 Corruption Perceptions Index

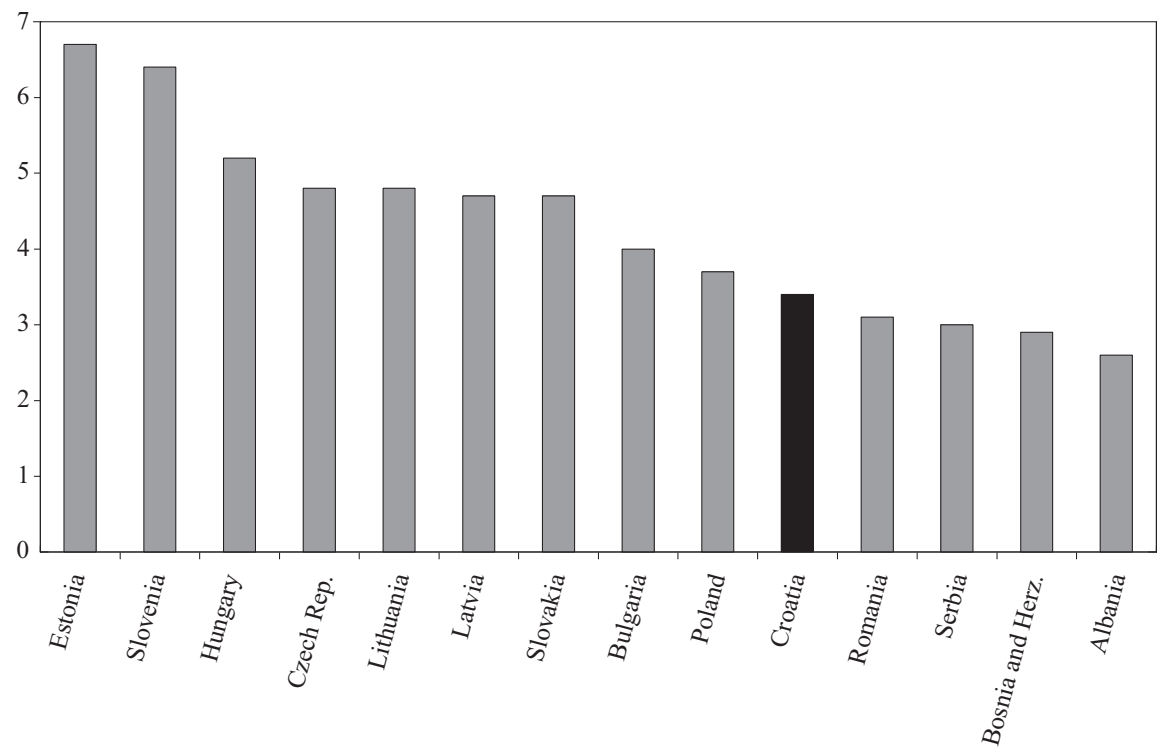

Source: Transparency International.

to growth - for example, significant reductions in expenditure that would allow for both a lower fiscal deficit as well as tax cuts - would yield their full benefits only if the business environment is improved as well.

The possibility that human capital problems are also constraining economic growth warrants further study, and a measured policy response. Growth will not necessarily be boosted simply by allocating more resources to education: Croatia already performs favorably on broader indicators of education and literacy. More difficult measures may nevertheless be much more fruitful. In response to the problem of insufficiently skilled employees, encouraging "lifelong learning" could boost labor productivity and growth. Also, consolidating the numerous welfare benefits, which often overlap and may be subject to abuse, could help address disincentives to labor-market participation.

\section{LITERATURE}

Aghion, P. and Durlauf, S. N., 2005. Handbook of Economic Growth. Amsterdam: North-Holland. 
Barro, R. and Sala-í-Martin, X., 2004. Economic Growth. New York: McGraw Hill.

Bejaković, P. and Lowther, J. (eds.), 2004. The Competitiveness of Croatia's Human Resources. Zagreb: Institute of Public Finance.

Berthélemy, J.-C., Dessus, S. and Nahas, C., 2007. “Exploring Lebanon's Growth Prospects." World Bank Policy Research Working Paper, No. 4332. Washington: The World Bank.

Demekas, D. [et al.], 2005. "Foreign Direct Investment in Southeastern Europe: How (and How Much) Can Policies Help?" IMF Working Paper, WP/05/110. Washington: International Monetary Fund.

Ederer, P., Schuler, P. and Willms, S., 2007. The European Human Capital Index: The Challenge of Central and Eastern Europe. Lisbon Council Policy Brief. Brussels: The Lisbon Council for Economic Competitiveness and Social Renewal.

European Commission, 2006. Croatia 2006 Progress Report. Commission Staff Working Document SEC (2006) 1385. Brussels: Commission of the European Communities.

Fischer, S., 1993. “The Role of Macroeconomic Factors in Growth.” Journal of Monetary Economics, 32 (3), 485-512.

George, D. A. R., Oxley, L. and Carlaw, K. I., 2004. Surveys in Economic Growth: Theory and Empirics. Oxford: Blackwell.

Government of the Republic of Croatia, 2006. Strategic Development Framework for 2006-2013. Zagreb: Central Office for Development Strategy and Coordination of EU Funds.

Gueorguiev, N., 2007. "Economic Effects of Reducing the Size of Government in Croatia: A Note Based on the IMF's Global Fiscal Model" in: Republic of Croatia: Selected Issues. IMF Country Report, No. 07/82. Washington: International Monetary Fund.

Hausmann, R., Rodrik, D. and Velasco, A., 2005. "Growth Diagnostics" [online]. Working paper. Available from: [http://ksghome.harvard.edu/ rhausma/new/growthdiag.pdf].

Helpman, E., 2004. The Mystery of Economic Growth. Cambridge, MA: Belknap Press of Harvard University Press.

Hilaire, A. and Ilyina, A., 2007. "External Debt and Balance-Sheet Vulnerabilities in Croatia" in Republic of Croatia: Selected Issues. IMF Country Report, No. 07/82. Washington: International Monetary Fund.

Hodrick, R. and Prescott, E. C., 1997. "Postwar U.S. Business Cycles: An Empirical Investigation." Journal of Money, Credit, and Banking, 29 (1), 1-16.

Klinger, B. and Lederman, D., 2006. "Diversification, Innovation, and Imitation inside the Global Technological Frontier." World Bank Policy Research Working Paper, No. 3872. Washington: World Bank.

Levine, R. and Renelt, D., 1992. “A Sensitivity Analysis of Cross-Country Growth Regressions." American Economic Review, 82 (4), 942-63. 
Megginson, W. L. and Netter, J. M., 2001. "From State to Market: A Survey of Empirical Studies on Privatization.” Journal of Economic Literature, 39 (2), 321-89.

Mervar, A. and Nestić, D., 1999. "Macroeconomic Policy and Economic Growth in Croatia: Recent Developments and Perspectives." Croatian Economic Survey, 4 (19961999), 121-44.

Mihaljek, D., 2001. “Toward a Long-Term Strategy of Economic Development of Croatia: Where to Begin, What to Do, and How to Do It?" [online]. Occasional Paper, No. 11. Available from: [http://www.ijf.hr/OPS/11.pdf].

Mihaljek, D., 2005. "EU Entrants, Candidates and Aspirants: How Large are the Differences and How Quickly Could They Be Reduced?" Ekonomski pregled, 56 (11), 975-95.

Mitra, S., 2007. "Bank Stability and Credit Risk in Croatian Banks" in: Republic of Croatia: Selected Issues. IMF Country Report, No. 07/82. Washington: International Monetary Fund.

OECD, 2006. OECD Employment Outlook: Boosting Jobs and Incomes. Paris: Organisation for Economic Co-operation and Development.

Pushak, T., Tiongson, E. R. and Varoudakis, A., 2007. "Public Finance, Governance, and Growth in Transition Economies: Empirical Evidence from 1992-2004." World Bank Policy Research Working Paper, No. 4255. Washington: World Bank.

Richter, K., 2006. "Thailand's Growth Path: From Recovery to Prosperity." World Bank Policy Research Working Paper, No. 3912. Washington: World Bank.

Šonje, V., 1999. "Financial Development and Economic Growth." Croatian Economic Survey, 4 (1996-1999), 207-246.

Šošić, V., 2004. "Does it Pay to Invest in Education in Croatia? Return to Human Capital Investment as a Factor in Human Resource Competitiveness" in: P. Bejaković and J. Lowther, eds. The Competitiveness of Croatia's Human Resources, 22-58. Zagreb: Institute of Public Finance.

Temple, J., 2000. "Growth Regressions and What the Textbooks Don't Tell You." Bulletin of Economic Research, 52 (3), 181-205.

Tonin, M., 2005. "Updated Employment Protection Legislation Indicators for Central and Eastern European Countries" [online]. Working paper. Institute for International Economic Studies, Stockholm University. Available from:

[http://www.iies.su.se/ tonin/mirco_files/MircoToninEPLIndicatorsPaper.pdf].

Vamvakidis, A., 2007. "External Debt and Economic Reform." IMF Working Paper, WP/07/50. Washington: International Monetary Fund.

Vrbanc, I., 2006. Estimate of Potential Growth Domestic Product Using the Production Function Method. Paper Presented at the 12th Dubrovnik Economic Conference.

Vujčić, B. and Lang, M., 2002. GDN Project Country Study: Croatia. Riga: Global Development Network. 
World Bank, 2005. Bolivia: Country Economic Memorandum - Policies to Improve Growth and Employment. Report No. 32233-BO. Washington: World Bank.

World Bank, 2006. Kingdom of Morocco: Country Economic Memorandum - Fostering Higher Growth and Employment with Productive Diversification and Competitiveness. Report No. 32948-MOR. Washington: World Bank. 


\section{Appendix}

Determinants of Growth: Croatia and the Rest of Europe, 2001-2005

\begin{tabular}{cccc} 
Croatia & $\begin{array}{c}\text { SEE } \\
\text { (excluding } \\
\text { Croatia) }\end{array}$ & CEE & $\begin{array}{c}\text { Euro Source } \\
\text { area }\end{array}$ \\
\hline
\end{tabular}

\section{Growth}

Real GDP growth, 2002-2005

\section{Convergence}

Real GDP per capita, PPP adjusted, in $\%$ of euro area, 2005

\section{Population}

Age dependency ratio, 2004

Population growth (in \%), 2002-2004

\section{Investment}

Gross fixed capital formation (in \% of GDP),

2002-05

$$
\text { private }
$$

public

Foreign direct investment, inflows

(in \% of GDP), 2002-2005

\section{Fiscal policy}

General government balance

(in \% of GDP), 2005

General government, total expenditure and net lending (in \% of GDP), 2005

General government, gross debt (in percent of GDP), 2005

\section{Monetary policy}

CPI inflation (in \%), 2005

Sound money (index, increasing from 1 to 10), 2004

\section{Transition}

Average transition (index, increasing from 1 to 5), 2005

Economic freedom index (index, increasing from 1 to 10$), 2004$

Size of government (index, increasing from 1 to 10), 2004

\section{Financial sector development}

M2 (in \% of GDP), 2004

Domestic credit to private sector

(in \% of GDP), 2004

$\begin{array}{ll}4.8 & 5.8\end{array}$

1.2 WEO

42.7

$\begin{array}{llll}31.8 & 53.1 & 100.0 \quad \text { WEO }\end{array}$

0.5

0.5

0.0

$-0.1-0.3$

0.5 WDI

0.5 WDI

27.5

$$
21.6
$$

24.3

20.2 WEO

20.7

6.8

4.8

$\begin{array}{ll}17.0 & 22.0\end{array}$

... WEO

... WEO

$$
4.8
$$

49.0

$4.6 \quad 3.5$

3.5 WEO

$5.3 \quad 5.6$

(5)

$\begin{array}{lrrrr}-4.1 & -0.3 & -2.5 & -2.3 & \text { WEO } \\ 49.0 & 38.9 & 40.5 & 47.5 & \text { WEO } \\ 44.3 & 33.7 & 23.8 & 70.8 & \text { WEO }\end{array}$

$\begin{array}{lllll}3.3 & 5.5 & 3.4 & 2.2 & \text { WEO }\end{array}$

$\begin{array}{lllll}8.1 & 8.2 & 9.2 & 9.6 & \mathrm{EFN}\end{array}$

$\begin{array}{rrrrr}3.4 & 3.0 & 3.7 & \ldots & \text { EBRD } \\ 6.2 & 5.9 & 7.1 & 7.5 & \text { EFN } \\ 4.0 & 4.5 & 5.7 & 5.3 & \text { EFN } \\ & & & & \\ 64.5 & 44.6 & 45.8 & 72.9 & \text { WDI } \\ 57.5 & 28.4 & 36.0 & 106.0 & \text { WDI }\end{array}$

\section{Business environment}

Business regulations

(index, increasing from 1 to 10), 2004

$\begin{array}{lllll}5.1 & 4.7 & 5.9 & 6.3 & \text { EFN }\end{array}$


Cost of business start-up procedures ( $\%$ of GNI per capita), 2004

Time required to start a business (days), 2004

Corruption (\% of managers surveyed ranking

this as a major business constraint), 2002

\begin{tabular}{|c|c|c|c|c|}
\hline 14.4 & 19.9 & 12.6 & 11.9 & WDI \\
\hline 49.0 & 44.0 & 41.6 & 37.1 & WDI \\
\hline 22.5 & 30.0 & 15.6 & $\ldots$ & WDI \\
\hline 3.0 & 2.5 & 3.2 & $\ldots$ & EBRD \\
\hline 102.8 & 108.0 & 131.1 & 73.9 & WEO \\
\hline 6.7 & 6.6 & 7.9 & 8.1 & EFN \\
\hline 87.3 & 93.6 & 90.3 & 99.4 & WDI \\
\hline 85.0 & 84.6 & 90.1 & 92.2 & WDI \\
\hline 24.0 & 14.4 & 18.3 & 18.3 & WDI \\
\hline 23.5 & 13.4 & 22.5 & 26.3 & WDI \\
\hline 8.7 & 8.0 & 12.9 & $\ldots$ & WDI \\
\hline 12.7 & 19.8 & 10.6 & 8.6 & WEO \\
\hline 56.4 & $\ldots$ & 50.9 & 43.1 & WDI \\
\hline 65.5 & 67.4 & 68.2 & 69.8 & WDI \\
\hline 57.0 & 43.5 & 35.1 & 49.1 & WDI \\
\hline 75.4 & 73.7 & 73.1 & 79.4 & WDI \\
\hline 7.8 & 7.6 & 6.7 & 9.6 & WDI \\
\hline 1.3 & 2.9 & 1.7 & 2.5 & WDI \\
\hline 6.5 & 4.7 & 5.0 & 7.1 & WDI \\
\hline 1.1 & 0.5 & 0.8 & 2.2 & WDI \\
\hline 189.5 & 148.5 & 309.6 & 420.8 & WDI \\
\hline 293.3 & 187.8 & 360.6 & 443.2 & WD \\
\hline
\end{tabular}

Infrastructure

Overall infrastructure reform (index, increasing from 1 to 5), 2005

\section{International trade}

Trade (\% of GDP), 2005

Freedom to trade internationally (index, increasing from 1 to 10), 2004

\section{Human capital}

Primary school enrollment ratio

(in \% of relevant age group), 2003

Secondary school enrollment ratio

(in \% of relevant age group), 2003

Expenditure per student, primary

(in \% of GDP per capita), 2002

Expenditure per student, secondary

(in \% of GDP per capita), 2002

Labor skills ( $\%$ of managers surveyed ranking this

as a major business constraint), 2002

\section{Labor market}

Unemployment rate (in \%), 2005

Long-term unemployment (in \% of total

unemployment), 2002

Labor force participation rate (in \%), 2004

Rigidity of employment index

$(0=$ less rigid to $100=$ more rigid $), 2004$

\section{Health}

Life expectancy at birth, total (years), 2004

Health expenditure, total (in \% of GDP), 2003

private

public

\section{New economy}

Research and development expenditure

(in \% of GDP), 2003

Personal computers (per 1,000 people), 2004

Internet users (per 1,000 people), 2004

South Eastern European (SEE) countries: Albania, Bosnia \& Herzegovina, Bulgaria, FYR Macedonia, Romania, Serbia \& Montenegro, Slovenia.

Central Eastern European (CEE) countries: Czech Republic, Estonia, Hungary, Latvia, Lithuania, Poland, Slovak Republic.

Sources: IMF World Economic Outlook (WEO), World Bank World Development Indicators (WDI), European Bank of Reconstruction and Development (EBRD), Economic Freedom Network (EFN), UNESCO. 